\title{
Soil water content variations and hydrological relations of the cropland-treebelt-desert land use pattern in an oasis-desert ecotone of the Heihe River Basin, China
}

\author{
Qin Shen ${ }^{\mathrm{a}, \mathrm{b}}$, Guangyao Gao ${ }^{\mathrm{a}, *}$, Bojie Fu ${ }^{\mathrm{a}}$, Yihe Lü $^{\mathrm{a}}$ \\ a State Key Laboratory of Urban and Regional Ecology, Research Center for Eco-Environmental Sciences, Chinese Academy of Sciences, Beijing 100085, China \\ ${ }^{\mathrm{b}}$ University of Chinese Academy of Sciences, Beijing 100049, China
}

\section{A R T I C L E I N F O}

\section{Article history:}

Received 11 December 2013

Received in revised form 7 July 2014

Accepted 11 July 2014

Available online 2 August 2014

\section{Keywords:}

Soil water content

Hydrological relation

Land use pattern

Oasis-desert ecotone

Heihe River Basin

\begin{abstract}
A B S T R A C T
This study considered the cropland-treebelt-desert system in the arid inland river basin as an entire continuum to investigate the soil water content variation and hydrological relation. For this objective, the volumetric soil water content and plant root distribution was measured to $300 \mathrm{~cm}$ depth along a cropland-treebelt-desert site at the oasis-desert ecotone in the Heihe River Basin, China. The results showed that the mean soil water content in the $0-200 \mathrm{~cm}$ layer was greater in the cropland (8.88\%) than that in the treebelt (5.78\%) and desert (4.37\%) as a result of frequent irrigation events. However, the cropland had noticeably lower mean soil water content below $200 \mathrm{~cm}$ depth (14.27\%), compared to treebelt (18.07\%) and desert (17.30\%) with deeper roots to suck up groundwater. The decline process in soil water content pulse of the cropland and treebelt after irrigation event could be well described by an exponential decay function, and the soil water loss rate was greater in the cropland $(0.45-0.70 \% /$ day $)$ than that in the treebelt $(0.32-0.47 \% /$ day $)$. The hydrological relation between treebelt and cropland in the upper soil layer was mainly occurred by treebelt root water uptake from cropland. The biomass of fine treebelt root extended into the cropland decreased logarithmically with the distance from the cropland-treebelt interface, which resulted in the smaller soil water content in the cropland with more proximity to the treebelt. The hydrological relation in the lower soil layer among cropland-treebelt-desert was caused by groundwater recharge, as cropland irrigation raised up the groundwater level to replenish the deep soil layer. The results indicated that the percolation in the cropland was an important water source for the growth of treebelt and desert plants. This study could provide scientific basis for land use pattern design and water resources management in the arid inland river basin.
\end{abstract}

(c) 2014 Elsevier B.V. All rights reserved.

\section{Introduction}

Water resources play an important role in the development of oasisdesert ecosystems in the arid inland river basins (Wang and Cheng, 1999). A shortage of water resource in these areas has become an increasingly serious problem because of over-consumption by agricultural irrigation and human and industrial uses. This change substantially results in the response of hydrological cycles and degradation of the distinctive ecosystems (Wang et al., 2007a,b). Soil water is a critical component of the hydrological cycle and an essential mediator between land surface and atmospheric interactions (Mahmood and Hubbard, 2007). It is involved in many hydrological processes, including infiltration from rainfall, drainage to deeper layers, and discharge from groundwater, as well as root uptake and evapotranspiration. Soil

\footnotetext{
* Corresponding author. Tel.: + 861062911239.

E-mail address: gygao@rcees.ac.cn (G. Gao).
}

water content is a typical indicator of water limitation in dryland ecosystems (Porporato et al., 2002).

Many studies have been conducted to examine the soil water content dynamics in the oasis-desert ecosystems of arid inland river basin. The studies typically focused on the soil water content variations and the influencing factors of single land use type, e.g., the cropland (Ji et al., 2007), grassland (Coronato and Bertiller, 1996), artificial forest (Knight et al., 2002) and desert (Li et al., 2008). The effects of soil texture, root distribution and groundwater recharge on soil water content variations were investigated (Dodd and Lauenroth, 1997; Kizito et al., 2007). The effects of land use and soil texture on spatial variability of soil water content were also conducted in the Chinese Loess Plateau (Fu et al., 2003; Hu et al., 2008, 2011; Huang et al., 2012). Singh et al. (1998) found that the soil water content profile in the shortgrass steppe was determined by the soil texture and root distribution, and it was higher in a clay loam site than that in a sandy loam site. Kizito et al. (2007) found that shrub had a positive effect on the field moisture regime as it had deep root distribution to compete with the crops for water from the deep soil layers and groundwater. Furthermore, it has 
recently been demonstrated that the soil water content was inversely correlated with the biomass of above ground vegetation (Wang et al., 2007a,b).

The combinations of land use or vegetation types had substantial effects on soil water content dynamics in arid and semi-arid regions (Ruiz-Sinoga et al., 2011; Valentin et al., 1999). In the oasis-desert ectone of an arid inland river basin, there are many representative land use patterns such as cropland-treebelt, treebelt-desert and cropland-treebelt-desert. The studies on soil water content variations among the agroforestry system are becoming prevalent because of the need to reduce agricultural water use (Campi et al., 2009). These studies primarily concentrated on comparing the water use of adjacent land use types and the hydrological interactions between them, such as cropland and treebelt (Ellis et al., 2005), or treebelt and pasture (Knight et al., 2002). The results showed that treebelt could use soil water from the adjacent cropland or pasture within a few metres' distance. This conclusion was supported by the findings of Woodall and Ward (2002) who reported that tree-crop competition for soil water reduced wheat growth and grain yield to a distance of $20-30 \mathrm{~m}$ from the trees. Livesley et al. (2004) found that soil water content in an alley cropping system varied spatially with the distance from a tree row.

The Heihe River is one of the largest inland rivers in the arid zones of northwest China. The studies on soil water content in the oasis-desert ecotone of the basin mainly focused on the relationship between soil water content and plant species diversity, and the spatial variability of soil water content and vegetation along the oasis-desert ecotone. Li et al. (2008) found that the shallow soil water content mainly influenced the diversity of herbaceous species, especially the annual and ephemeral plants, whereas the diversity of woody species evidently depended on deeper soil water content. The soil water content and vegetation existed strong distribution pattern of spatial heterogeneity representing a random distribution on a small scale $(<100 \mathrm{~m})$ and a mass distribution structure on a larger scale (100-3100 m) (Wang et al., 2007a,b). Despite these studies, the comparison of soil water content variations in different layers among cropland, treebelt and desert, and the integrated effects of irrigation, land use type and groundwater fluctuation on soil water content variations should be substantially addressed. Furthermore, there were few studies considering the cropland-treebelt-desert land use pattern as an entire continuum to investigate the inside soil water content dynamics and hydrological relations, which are very useful for the management of basin water resources.

In this study, a cropland-treebelt-desert field site with shallow groundwater table was selected. The volumetric soil water content and plant root distribution was measured to the depth of $300 \mathrm{~cm}$ in the site during the maize growing season in 2012. The main objectives were to (1) compare profile distribution and temporal variations of soil water content between these three land use types, (2) investigate the water exchange among the cropland-treebelt-desert land use pattern, and (3) discuss the soil water content variations and hydrological relations in this land use pattern.

\section{Materials and methods}

\subsection{Study area}

The study area is located in a desert-oasis ecotone in the middle reach of the Heihe River Basin, in Linze County of Gansu province, China $\left(39^{\circ} 21^{\prime} \mathrm{N}, 100^{\circ} 07^{\prime} \mathrm{E}\right.$, altitude $\left.1374 \mathrm{~m}\right)$ (Fig. 1). The area has a continental arid temperate climate with an average annual rainfall of $116.8 \mathrm{~mm}$. The potential evaporation is $2390 \mathrm{~mm}$ year $^{-1}$, and the

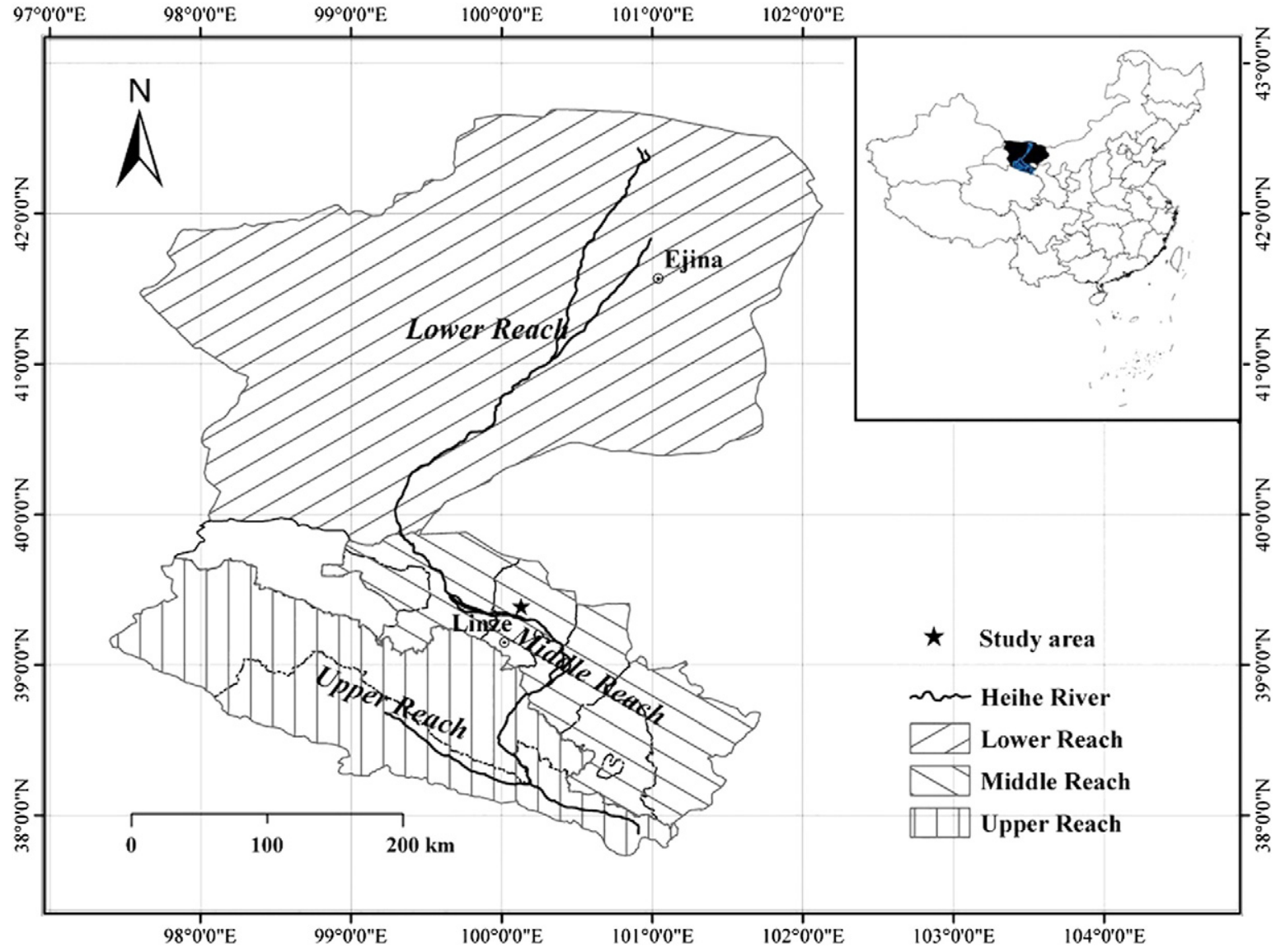

Fig. 1. Location of the study area in the Heihe River Basin, China. 
average annual temperature is $7.6{ }^{\circ} \mathrm{C}$ (Zhao and Liu, 2010). The main soil types are sand and sandy loam according to the USDA Soil Taxonomy, which had loose structure and low organic matter content (Su et al., 2007). The main land use types are cropland (e.g., maize and wheat), forestland (e.g., shelter belt, shrub belt and riparian forest belt), unused land (e.g., Gobi desert, bare land and desert), water area (e.g., wetland and reservoir) and residential area (Liu et al., 2010).

\subsection{Experimental design and measurements}

The experimental site was selected in a typical cropland-treebeltdesert system with the conversion of desert to treebelt and cropland at the edge of a new oasis. A narrow treebelt was bounded on the south by cropland and on the north by desert (Fig. 2a). The treebelt was established in 1982 with Gansu Poplar (Populus gansuensis). The desert was simultaneously planted with korshinsk peashrub (Caragana korshinskii). The cropland was farmed with maize (Zea mays) during March to September.

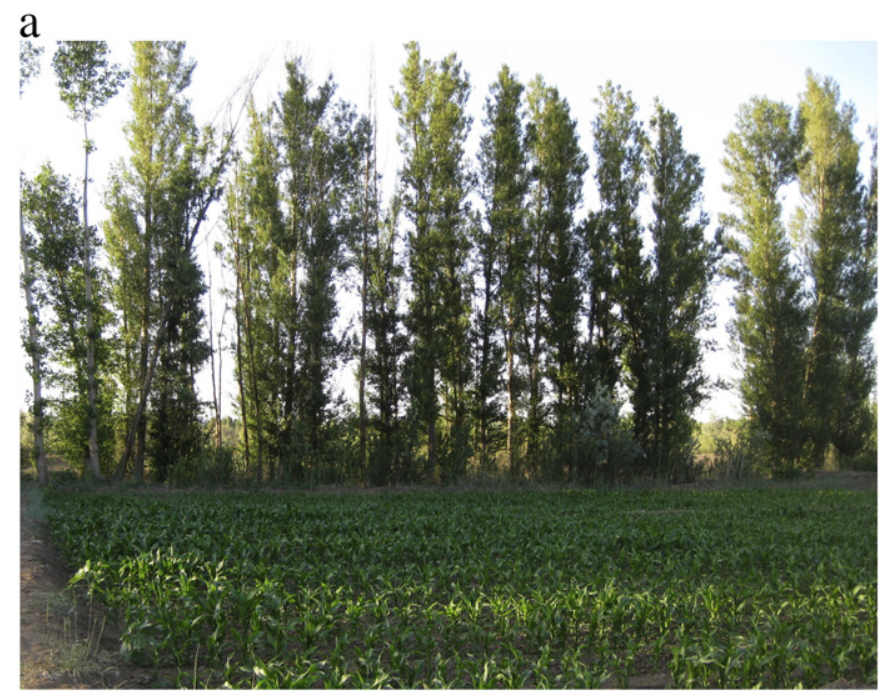

b

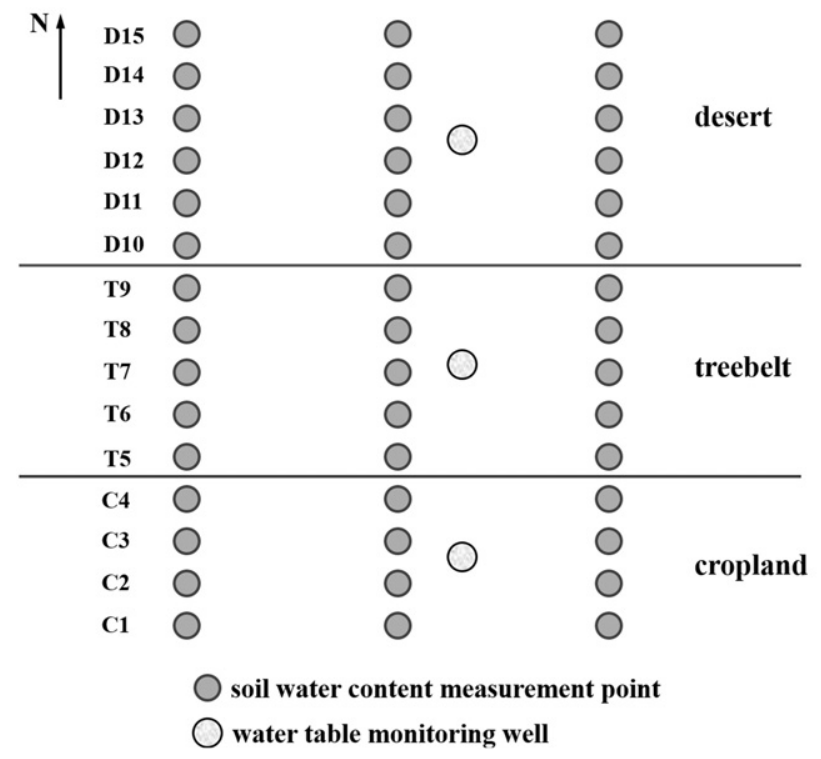

Fig. 2. Description of the experiment site: (a) picture of the cropland-treebelt-desert site, and (b) points of the soil water content measurement and water table monitoring well in the site.
Three transects with $6 \mathrm{~m}$ intervals were laid out along the croplandtreebelt-desert site (Fig. 2b). Four, five and six Trime-TDR access tubes (4-cm diameter, polycarbonate) with $3 \mathrm{~m}$ depth to measure volumetric soil water content were installed in the cropland, treebelt and desert of each transect, respectively. The distance between adjacent tubes was 4 $m$ along the transect. In total, there were twelve, fifteen and eighteen measurement points in the cropland, treebelt and desert, respectively, which could definitely represent the soil water variations in each field site. The volumetric soil water content was measured by TDR (TRIMETDR-PICO-IPH-T3, Imko, Germany) at $20 \mathrm{~cm}$ intervals to a depth of $300 \mathrm{~cm}$ periodically (every 5 days) during the study period from April 19 to October 16, 2012. Additional measurements were performed before and after irrigation and rainfall events. The measured soil volumetric moisture was calibrated in the field with the gravimetric method under both the dry and wet conditions. In the following analysis, the "soil water content" all referred to the "volumetric soil water content".

Soil samples were obtained with $20 \mathrm{~cm}$ depth interval from the soil surface to $300 \mathrm{~cm}$ depth. The soil sample location had distance of $40 \mathrm{~cm}$ away from that each TDR tube set up. These samples were analysed in the laboratory for the soil physical and chemical properties, including the soil mechanical composition (Mastersizer 2000, Malvern Instruments, England), $\mathrm{pH}$ (1: 2.5 soil: water), soil organic matter (SOM) (Walkley-Black method), total carbon (TC) and total nitrogen (TN) (Vario EL III, Elementar, German). Furthermore, a soil profile was dug to $300 \mathrm{~cm}$ depth in each land use type. Undisturbed soil samples were taken from the soil profile in every $20 \mathrm{~cm}$ depth with three replications using standard pre-weighed $100 \mathrm{ml}$ Kopecki rings (a core sampling device). The soil samples were collected to measure the bulk density ( $\mathrm{BD}$, gravimetric method), soil water retention curve (Hitachi-CR21G, Hitachi, Japan) and saturated hydraulic conductivity $\left(K_{s}\right.$, constant head method). The soil profile was divided into five layers $(0-20 \mathrm{~cm}$, 20-120 cm, 120-160 cm, 160-240 cm and 240-280 cm) according to the measured soil properties (Table 1 ).

To investigate the root distribution of maize, Gansu Poplar and korshinsk peashrub, plant roots were picked from soil samples at $20 \mathrm{~cm}$ intervals obtained in the cropland, treebelt and desert profiles, respectively. To obtain the extension of treebelt root to cropland, additional twelve sites were chosen in the cropland with the maximum distance of $18 \mathrm{~m}$ from the treebelt-cropland interface, and the treebelt roots were picked to the depth of $300 \mathrm{~cm}$ in each site. With the obtained root samples, the biomass of fine root $(<2 \mathrm{~mm})$ was measured.

One groundwater level monitoring well was established in each land use type along the middle transect (Fig. 2b). The water table was automatically recorded every 20 min by the water level logger (Hobo U20-001-04, Onset Computer Corporation, USA). The fluctuation of water table depth during the study period was shown in Fig. 3. The variation of water table was closely related to the local groundwater movement, and the irrigation event resulted in the differences of water table between the three land use types.

The cropland was irrigated by conventional flood irrigation once every 7 to 14 days with the irrigation amount of approximate 100 $\mathrm{mm}$. As shown in Fig. 3, ten irrigation events occurred in the cropland on May 20, June 3, June 16, June 25, July 7, July 15, July 24, August 3, August 16 and August 27, respectively. The treebelt was irrigated once on June 20 with the irrigation amount of approximate $250 \mathrm{~mm}$ (Fig. 3). Daily rainfall and other climatic factors were logged using an AG1000 automated weather station. During the experimental period, there were 18 rainfall events, which produced a total rainfall of $90.6 \mathrm{~mm}$ accounting for $87 \%$ of annual rainfall (Fig. 3).

\subsection{Data analysis}

The soil water content was measured with depth increments of $20 \mathrm{~cm}$. We denoted the $0-20,20-40 \ldots . .260-280 \mathrm{~cm}$ depth as $d_{1}, d_{2} \ldots . . d_{14}$, 
Table 1

Soil physical and chemical properties in the cropland, treebelt and desert.

\begin{tabular}{|c|c|c|c|c|c|c|c|c|c|c|}
\hline Land use type & Soil layer $(\mathrm{cm})$ & Sand (\%) & Silt (\%) & Clay (\%) & $\mathrm{BD}^{\mathrm{a}}\left(\mathrm{g} / \mathrm{cm}^{3}\right)$ & $K_{\mathrm{s}}{ }^{\mathrm{b}}(\mathrm{mm} / \mathrm{min})$ & $\mathrm{pH}$ & $\mathrm{SOM}^{\mathrm{c}}(\mathrm{g} / \mathrm{kg})$ & $\mathrm{TC}^{\mathrm{d}}(\mathrm{g} / \mathrm{kg})$ & $\mathrm{TN}^{\mathrm{e}}(\mathrm{g} / \mathrm{kg})$ \\
\hline \multirow[t]{5}{*}{ Cropland } & $0-20$ & 82.04 & 16.23 & 1.74 & 1.462 & 0.573 & 8.97 & 7.187 & 14.218 & 0.585 \\
\hline & $20-120$ & 89.67 & 9.19 & 1.14 & 1.591 & 0.748 & 9.00 & 1.605 & 8.740 & 0.135 \\
\hline & $120-160$ & 89.50 & 9.19 & 1.31 & 1.683 & 1.149 & 9.16 & 1.574 & 7.954 & 0.124 \\
\hline & $160-240$ & 93.44 & 6.09 & 0.47 & 1.649 & 0.566 & 9.14 & 1.530 & 7.042 & 0.087 \\
\hline & $240-280$ & 62.62 & 33.85 & 3.54 & 1.625 & 0.455 & 9.15 & 1.653 & 12.049 & 0.157 \\
\hline \multirow[t]{5}{*}{ Treebelt } & $0-20$ & 86.54 & 12.13 & 1.34 & 1.255 & 0.920 & 9.20 & 5.081 & 11.954 & 0.364 \\
\hline & $20-120$ & 91.00 & 8.15 & 0.84 & 1.604 & 0.711 & 9.00 & 1.305 & 8.901 & 0.121 \\
\hline & $120-160$ & 92.80 & 6.60 & 0.60 & 1.582 & 4.189 & 9.23 & 1.274 & 7.254 & 0.115 \\
\hline & $160-240$ & 87.15 & 11.61 & 1.24 & 1.645 & 1.283 & 9.22 & 1.124 & 5.967 & 0.075 \\
\hline & $240-280$ & 70.76 & 26.89 & 2.35 & 1.704 & 0.364 & 9.28 & 1.384 & 12.503 & 0.126 \\
\hline \multirow[t]{5}{*}{ Desert } & $0-20$ & 92.85 & 6.49 & 0.65 & 1.397 & 0.300 & 9.20 & 1.854 & 8.918 & 0.116 \\
\hline & $20-120$ & 92.15 & 7.13 & 0.72 & 1.540 & 1.066 & 9.00 & 1.364 & 8.440 & 0.101 \\
\hline & $120-160$ & 93.82 & 5.77 & 0.41 & 1.559 & 1.862 & 9.23 & 1.374 & 8.321 & 0.094 \\
\hline & $160-240$ & 89.16 & 10.04 & 0.79 & 1.627 & 0.278 & 9.22 & 1.437 & 7.329 & 0.089 \\
\hline & $240-280$ & 56.96 & 40.11 & 2.93 & 1.771 & 0.391 & 9.28 & 1.459 & 10.915 & 0.106 \\
\hline
\end{tabular}

${ }^{\mathrm{a}} \mathrm{BD}$ is the bulk density.

b $K_{\mathrm{s}}$ is the saturated hydraulic conductivity.

c SOM is the soil organic matter.

d $\mathrm{TC}$ is the total carbon.

e $\mathrm{TN}$ is the total nitrogen.

respectively. The mean soil water content at one depth $\left(\bar{\theta}_{d_{i}}\right)$ during the study period was calculated by the following equation:

$\bar{\theta}_{d_{i}}=\frac{1}{n T} \sum_{t=1}^{T} \sum_{j=1}^{n} \theta_{d_{i}, j, t}$

where $d_{i}$ denotes the $i$ th soil depth, $j$ is the measurement point, $t$ is the measurement occasion, and $n$ and $T$ are the total number of soil water content measurement points and occasions for one land use type, respectively.

The mean soil water content for all points at a given measurement time for $0-20,20-120,120-160,160-240,240-280 \mathrm{~cm}$ layers and the entire profile $(0-280 \mathrm{~cm})$ was calculated as follows:

$\bar{\theta}_{20, t}=\frac{1}{n} \sum_{j=1}^{n} \theta_{d_{1}, j, t} ; \bar{\theta}_{20-120, t}=\frac{1}{5 n} \sum_{j=1}^{n} \sum_{i=2}^{6} \theta_{d_{i}, j, t} ; \bar{\theta}_{120-160, t}=\frac{1}{2 n} \sum_{j=1}^{n} \sum_{i=7}^{8} \theta_{d_{i}, j, t} ;$

$\bar{\theta}_{160-240, t}=\frac{1}{4 n} \sum_{j=1}^{n} \sum_{i=9}^{12} \theta_{d_{i}, j, t} ; \bar{\theta}_{240-280, t}=\frac{1}{2 n} \sum_{j=1}^{n} \sum_{i=13}^{14} \theta_{d_{i}, j, t} ; \bar{\theta}_{0-280, t}=\frac{1}{14 n} \sum_{j=1}^{n} \sum_{i=1}^{14} \theta_{d_{i}, j, t}$

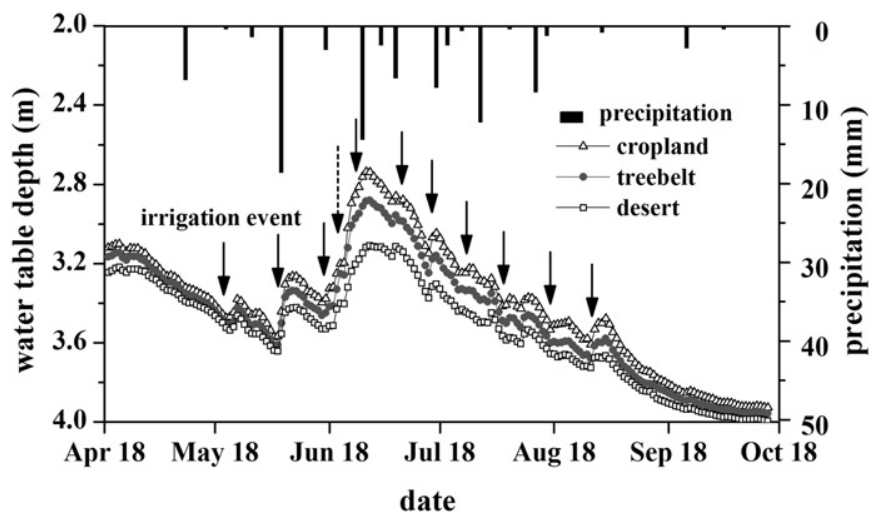

Fig. 3. The precipitation distribution, water table depth and irrigation events during the study period from April 19 to October 16. The short solid arrows represent the irrigation event in the cropland with amount of $100 \mathrm{~mm}$, while the long dotted arrow represents the irrigation event in the treebelt with amount of $250 \mathrm{~mm}$.
The mean soil water content of different soil layers and the entire profile $(0-280 \mathrm{~cm})$ during the study period for one land use type was calculated as follows:

$\bar{\theta}_{20}=\frac{1}{T} \sum_{t=1}^{T} \bar{\theta}_{20, t} ; \bar{\theta}_{20-120}=\frac{1}{T} \sum_{t=1}^{T} \bar{\theta}_{20-120, t} ; \bar{\theta}_{120-160}=\frac{1}{T} \sum_{j=1}^{n} \bar{\theta}_{120-160, t}$
$\bar{\theta}_{160-240}=\frac{1}{T} \sum_{t=1}^{T} \bar{\theta}_{160-240, t} ; \bar{\theta}_{240-280}=\frac{1}{T} \sum_{t=1}^{T} \bar{\theta}_{240-280, t} ; \bar{\theta}_{0-280}=\frac{1}{T} \sum_{t=1}^{T} \bar{\theta}_{0-280, t}$

The loss of soil water storage $(\Delta S)$ during the study period was calculated as follows:

$\Delta S=(\theta$ ini $-\theta$ end $) \times d$

soil water content $(\%)$

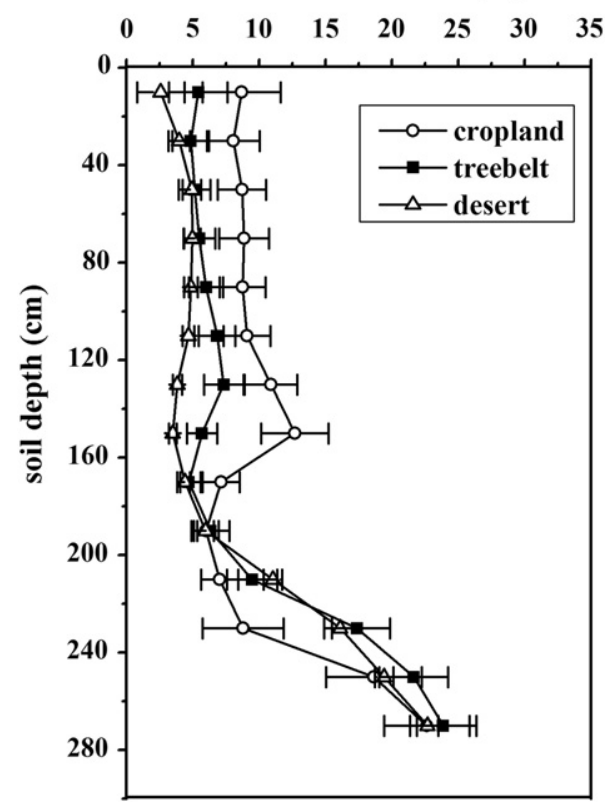

Fig. 4. The mean soil water content profile in cropland, treebelt and desert during the study period. The error bars represent the standard deviation for the mean values. 


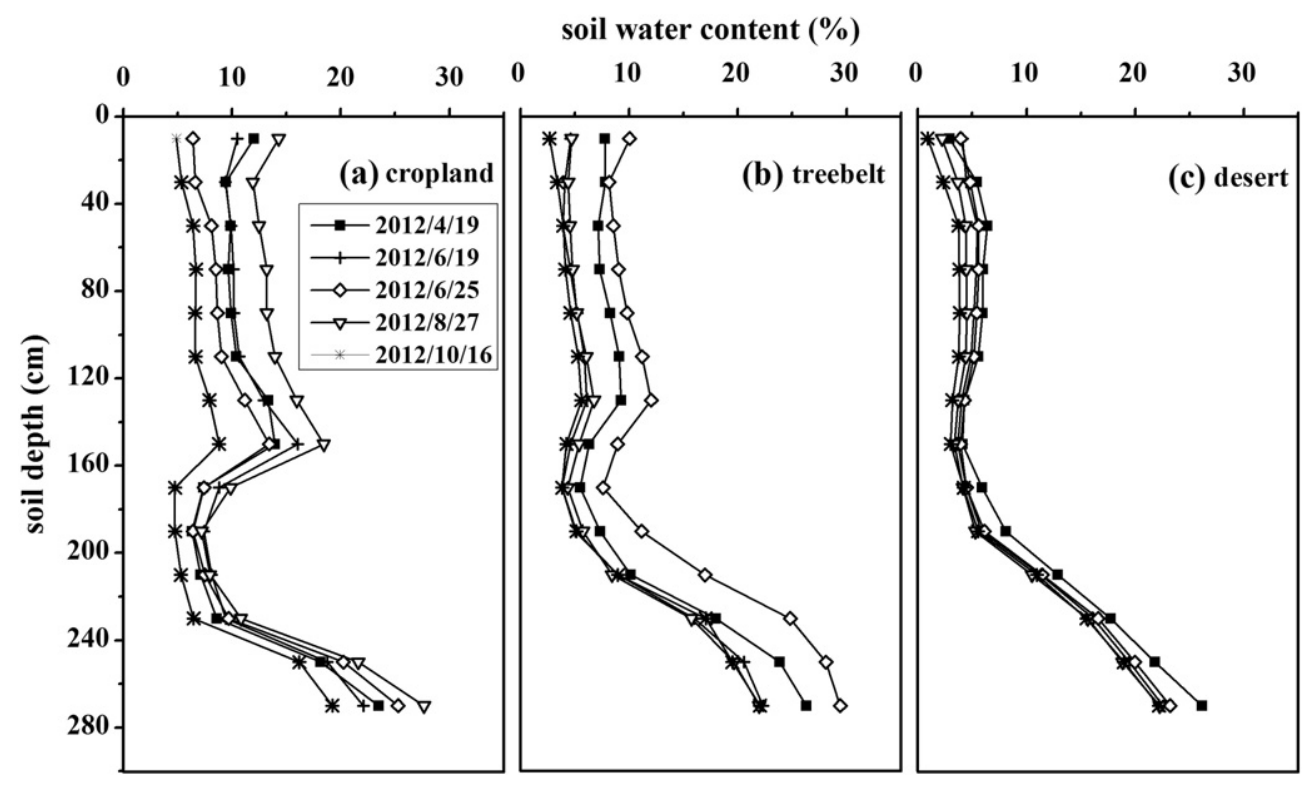

Fig. 5. The soil water content profile in (a) cropland, (b) treebelt and (c) desert at specific dates.

where $d$ is the thickness of soil layer, $\theta$ ini and $\theta$ end are the initial and final soil water content during the study period, respectively.

Basic population statistics, such as minimum values (Min), maximum values (Max), mean values (Mean) and coefficient of variation (CV) were reported for soil water content in different soil layers of each land use type. Analysis of variance (ANOVA) was performed to evaluate the differences in soil water content between different land use types, soil layers and measurement points. SPSS ${ }^{\circledR}$ (version 18.0) was used for all statistical analyses.

\section{Results}

\subsection{Soil water content profile of different land use types}

The profile distribution of mean soil water content during the study period of the three land use types calculated by Eq. (1) was given in Fig. 4 . The vertical distribution of the mean soil water content could be mainly divided into two layers. In the upper soil layer, there was slight difference between the soil water content of different depths. The soil water content in the cropland had an almost constant value of $8.68 \%$ at $0-120 \mathrm{~cm}$ depth following with some variation at $120-200 \mathrm{~cm}$ depth. The treebelt and desert had relatively constant soil water content of $5.78 \%$ and $4.37 \%$ at $0-200 \mathrm{~cm}$ depth, respectively. At the lower layer below $200 \mathrm{~cm}$ depth, the soil water content increased rapidly with depth for these three land use types. The value of soil water content increased from $7.03 \%$ to $22.63 \%, 9.46 \%$ to $23.85 \%$ and $11.04 \%$ to $22.67 \%$ in the cropland, treebelt and desert, respectively. As shown in Fig. 4, the mean soil water content at the $0-200 \mathrm{~cm}$ layer among the three land use types was significantly different $(p<0.05)$ in the descending order of cropland (8.88\%), treebelt (5.78\%) and desert (4.37\%). Below $200 \mathrm{~cm}$ depth, there was no significant difference between the soil water content of treebelt (18.07\%) and desert (17.30\%), whereas they were significantly $(p<0.05)$ higher than that of cropland $(14.27 \%)$.

The variations of soil water content profile in the three land use types on different dates were presented in Fig. 5. Similar vertical distributions of soil water content at specific time were observed as those of the mean soil water content profile as shown in Fig. 4. The soil water content profile in the cropland varied evidently in response to the irrigation event (Fig. 5a). Furthermore, the pronounced changes of soil water content in the cropland predominantly occurred above $160 \mathrm{~cm}$ depth as a result of irrigation replenishment, whereas the soil water content below $160 \mathrm{~cm}$ depth changed relative slightly. Except for soil water replenishment by the irrigation event on June 20 in the treebelt (Fig. 5b), the soil water content above $160 \mathrm{~cm}$ depth in treebelt and desert decreased uniformly and slightly as a result of evapotranspiration during the entire period, and the soil water content below $160 \mathrm{~cm}$ depth dropped to a stable value (Figs. 5b and 5c).

The mean soil water content in each soil layer (i.e., $0-20 \mathrm{~cm}, 20-120$ $\mathrm{cm}, 120-160 \mathrm{~cm}, 160-240 \mathrm{~cm}, 240-280 \mathrm{~cm}$ and 0-280 cm) calculated by Eq. (3) was compared between different land use types (Table 2).

Table 2

Soil water content of different soil layers in the cropland, treebelt and desert during the study period.

\begin{tabular}{|c|c|c|c|c|c|c|c|}
\hline Land use type & Statistics & $0-20 \mathrm{~cm}$ & $20-120 \mathrm{~cm}$ & $120-160 \mathrm{~cm}$ & $160-240 \mathrm{~cm}$ & $240-280 \mathrm{~cm}$ & $0-280 \mathrm{~cm}$ \\
\hline \multirow[t]{4}{*}{ Cropland } & Mean *(\%) & $8.68 c$ & $8.69 c$ & $11.78 \mathrm{c}$ & $7.24 b$ & $20.64 a$ & $10.42 c$ \\
\hline & $\operatorname{Max}(\%)$ & 17.42 & 14.80 & 17.60 & 11.66 & 28.57 & 15.69 \\
\hline & $\operatorname{Min}(\%)$ & 4.89 & 6.34 & 8.38 & 5.23 & 15.92 & 7.86 \\
\hline & $\mathrm{CV} * *(\%)$ & 34.01 & 20.95 & 18.86 & 21.98 & 16.25 & 18.25 \\
\hline \multirow[t]{4}{*}{ Treebelt } & Mean * $(\%)$ & $5.41 \mathrm{~b}$ & $5.66 \mathrm{~b}$ & $6.51 b$ & $9.46 a$ & $22.74 b$ & $9.29 b$ \\
\hline & $\operatorname{Max}(\%)$ & 13.13 & 9.34 & 10.48 & 15.13 & 29.04 & 13.98 \\
\hline & $\operatorname{Min}(\%)$ & 2.68 & 4.27 & 4.92 & 6.94 & 20.68 & 7.85 \\
\hline & $\mathrm{CV} * *(\%)$ & 40.81 & 22.52 & 19.98 & 17.12 & 11.19 & 16.87 \\
\hline \multirow[t]{4}{*}{ Desert } & Mean * $(\%)$ & $2.59 a$ & $4.68 \mathrm{a}$ & 3.66a & $9.38 \mathrm{a}$ & $21.03 a$ & $8.07 a$ \\
\hline & $\operatorname{Max}(\%)$ & 7.07 & 5.86 & 4.24 & 11.15 & 23.96 & 9.51 \\
\hline & $\operatorname{Min}(\%)$ & 0.89 & 3.50 & 3.10 & 8.40 & 19.77 & 7.22 \\
\hline & $\mathrm{CV} * *(\%)$ & 68.41 & 12.99 & 8.33 & 5.43 & 3.55 & 6.76 \\
\hline
\end{tabular}

\footnotetext{
* The significant differences among different land use types are indicated with different lowercase letters $(p<0.05)$.
}

** $\mathrm{CV}$ is the coefficient of variation. 
There were significant differences $(p<0.05)$ in the soil water content of the upper three layers between different land use types. The soil water content at the depth of $0-160 \mathrm{~cm}$ was in the order of cropland (9.46\%), treebelt (5.84\%) and desert (4.17\%), which was primarily because of irrigation in the cropland and treebelt. At the depth of $160-240 \mathrm{~cm}$, there was no significant difference between the soil water content of desert (9.38\%) and treebelt (9.46\%), whereas they were higher than that of cropland (7.24\%). At the depth of $240-280 \mathrm{~cm}$, the soil water content of cropland $(20.64 \%)$ and desert $(21.03 \%)$ were lower than that of treebelt (22.74\%).

\subsection{Soil water content temporal variations of different land use types}

The temporal variations of soil water content at different soil layers in the three land use types were shown in Fig. 6 . The time series of soil water content among these three land use types showed significant difference. The soil water content of the entire soil profile $(0-280 \mathrm{~cm})$ in the cropland was characterized by ten distinct pulses (Fig. 6a). The soil water content reached the peak in response to irrigation events and declined rapidly thereafter. There was one distinct soil water content pulse in the treebelt caused by the irrigation event on June 20 (Fig. 6a). The soil water content in the treebelt before and after this pulse was relatively stable. As shown in Fig. 6a, no drastic fluctuation of the soil water content in the desert was found, and it remained nearly constant during the study period.

Fig. 6b-f showed the temporal variations of soil water content in the 0-20 cm, 20-120 cm, 120-160 cm, 160-240 cm and 240-280 cm layers, respectively. The temporal variations were different in the upper and lower soil layers as a result of the different roles of precipitation, irrigation and groundwater. The soil water content in the deep soil layer was more stable than that in the shallow layer as indicated by the decreased coefficient of variation (CV) values with soil depth (Table 2). As shown in Figs. 6b-6d, there were ten and one distinct soil water content pulses in the upper soil layers $(0-20 \mathrm{~cm}, 20-120 \mathrm{~cm}$ and $120-160 \mathrm{~cm})$ of cropland and treebelt, respectively. The pulse in the $160-240 \mathrm{~cm}$ and 240-280 cm layers became evidently weak (Fig. 6e) as the soil water content in this layer of cropland and treebelt was affected by the combination of irrigation and groundwater fluctuation. The soil water content in the desert varied only in the $0-20 \mathrm{~cm}$ and $240-280 \mathrm{~cm}$ layers caused by precipitation and groundwater recharge, respectively, whereas it remained stable in the $20-240 \mathrm{~cm}$ layer as the limited precipitation was scarcely able to infiltrate into the deep soil layers.

A regression analysis was carried out to understand how the soil water content above the $160 \mathrm{~cm}$ depth decreased after irrigation event in the cropland and treebelt. As shown in Fig. 7, the decline of the soil water content at each soil layer could be well described by an exponential decay function with the larger values of $R^{2}$ (0.872-0.976). The soil water content loss rate could be ranked in the descending order of $0.70 \%$ day (0-20 cm layer), $0.47 \% /$ day (20-120 cm layer) and $0.45 \%$ /day $(120-160 \mathrm{~cm}$ layer) in the cropland, and $0.47 \% /$ day (0-20 cm layer), $0.36 \% /$ day $(20-120 \mathrm{~cm}$ layer) and $0.32 \% /$ day (120-160 cm layer) in the treebelt. The soil water loss rate decreased with the depth, and it was higher in the cropland than that in the treebelt at the identical soil layer.

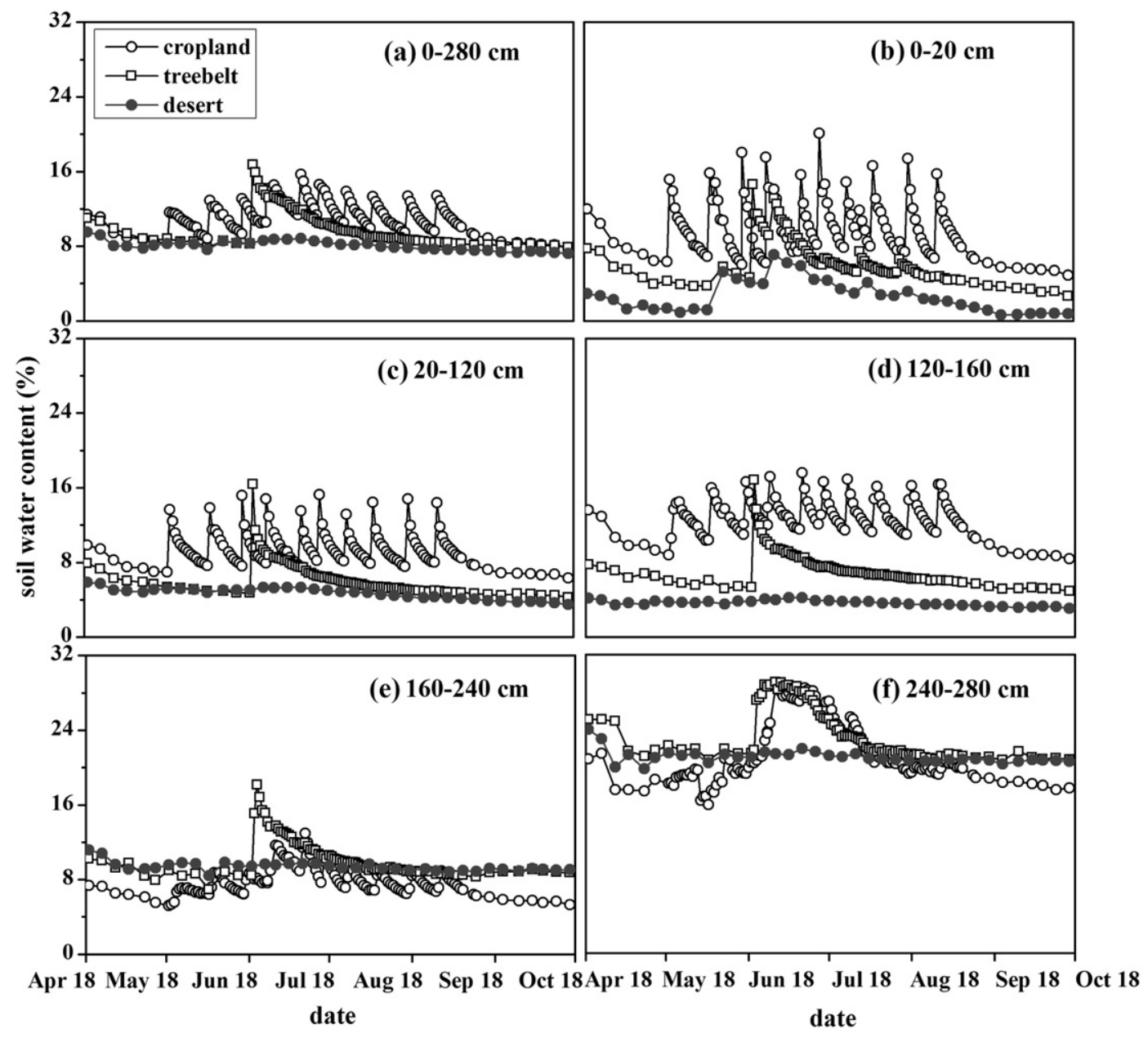

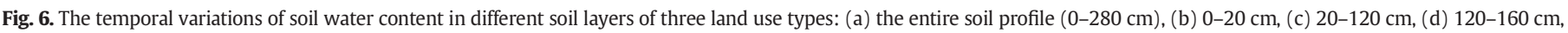
(e) $160-240 \mathrm{~cm}$ and (f) $240-280 \mathrm{~cm}$. 

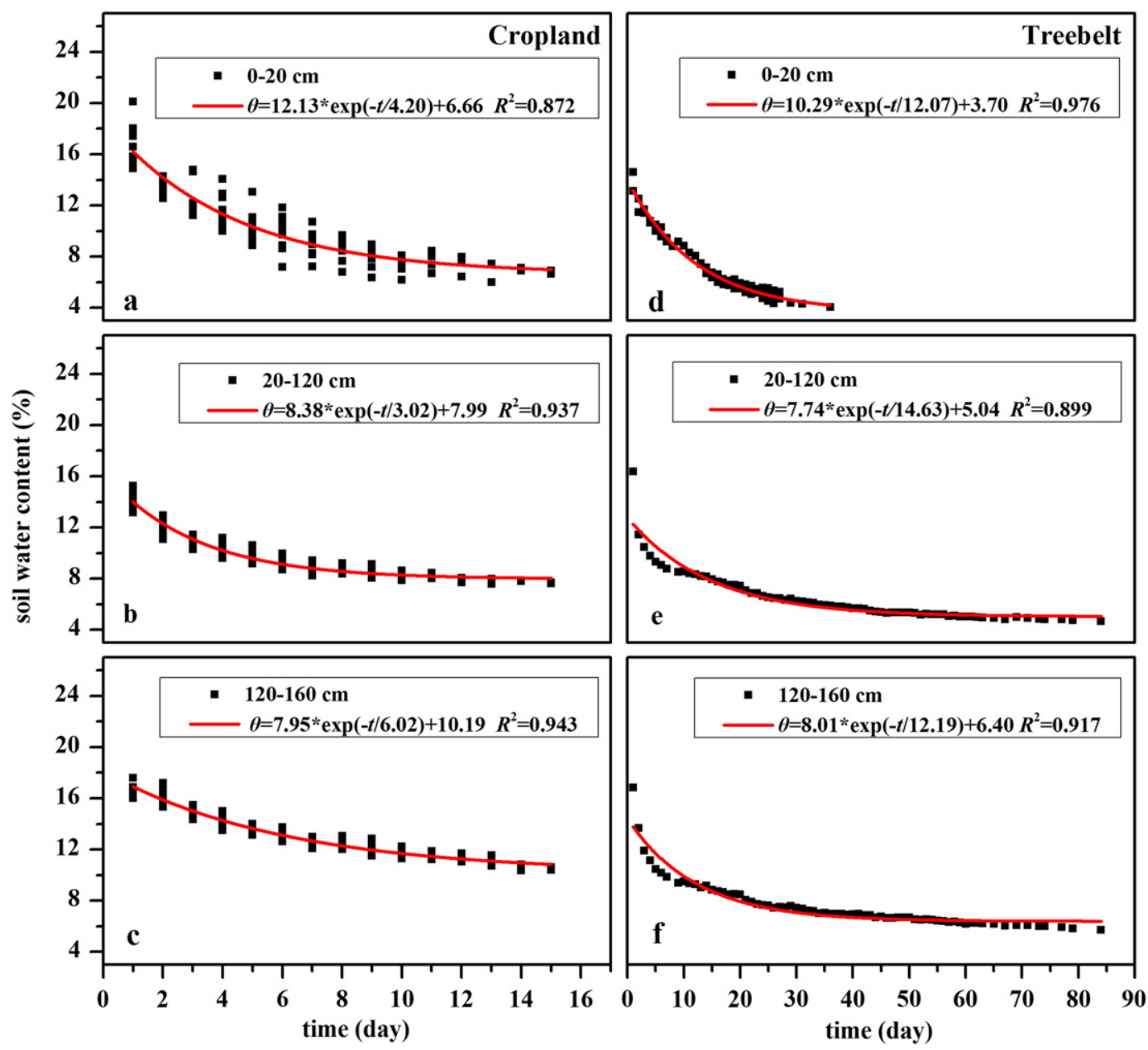

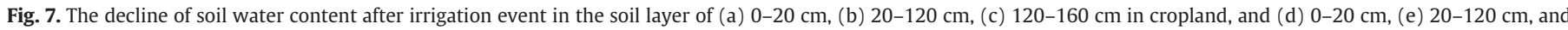
(f) $120-160 \mathrm{~cm}$ in treebelt fitted by an exponential decay function.

\subsection{Soil water content gradient along the land use pattern}

Soil water storage loss and mean soil water content of $0-160 \mathrm{~cm}$ layer in the four cropland points of $\mathrm{C} 1, \mathrm{C} 2, \mathrm{C} 3$ and $\mathrm{C} 4$ were shown in Fig. 8. The distances of these points from treebelt were $14 \mathrm{~m}, 10 \mathrm{~m}$, $6 \mathrm{~m}$ and $2 \mathrm{~m}$, respectively. The soil water storage loss in the cropland increased significantly with increasing proximity to the treebelt. The soil water storage loss of C4 point $(90.55 \mathrm{~mm})$ was one and half times as large as that of $\mathrm{C} 1$ point $(61.71 \mathrm{~mm})$. The larger soil water storage

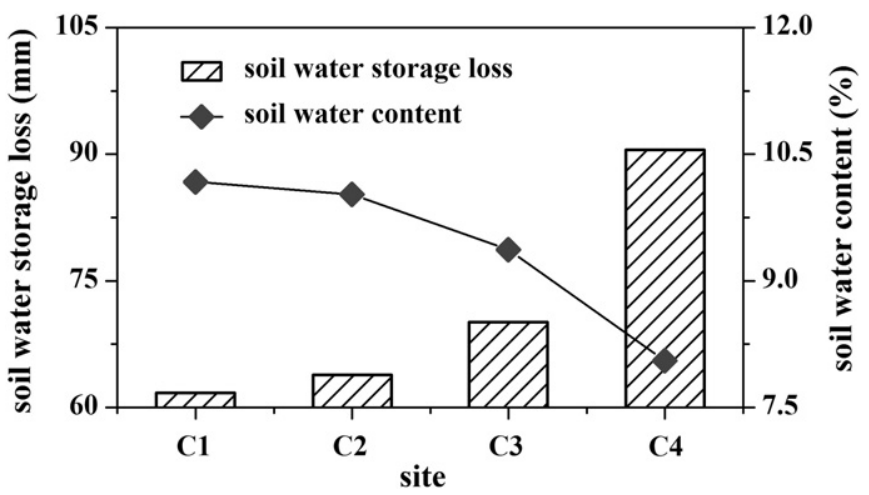

Fig. 8. The soil water storage loss and mean soil water content of $0-160 \mathrm{~cm}$ layer in the cropland at the four points of $C 1, C 2, C 3$ and $C 4$ with distances of $2 \mathrm{~m}, 6 \mathrm{~m}, 10 \mathrm{~m}$ and $14 \mathrm{~m}$ from the cropland-treebelt interface, respectively. resulted in the smaller soil water content in the cropland with more proximity to the treebelt as evident from Fig. 8. The mean soil water content of $0-160 \mathrm{~cm}$ layer in the $\mathrm{C} 1, \mathrm{C} 2, \mathrm{C} 3$ and $\mathrm{C} 4$ points were $10.17 \%, 10.02 \%, 9.37 \%$ and $8.05 \%$, respectively. Compared to the soil water content gradient in the cropland, the soil water content along the treebelt and desert did not show apparent regularity.

\section{Discussion}

\subsection{Soil water content differences among different land use types}

Soil water content is a critical variable for understanding many hydrological processes (Entin et al., 2000; Qiu et al., 2003). The soil water was replenished by infiltration from rainfall or irrigation and recharge from groundwater, and it moved upward from the soil by evaporation and root uptake for transpiration or was lost to deeper layers by drainage and percolation to groundwater. These inputs and outputs resulted in variable and continuous redistribution of water within the soils.

The differences of soil water content under the three land use types were compared at several soil layers. At the depth of $0-160 \mathrm{~cm}$, the conversion of desert to cropland and treebelt resulted in the increase of soil water content by over $5.29 \%$ and $1.67 \%$, respectively (Table 2 ). Obviously, the increase was caused by the irrigation occurrence in the cropland which could enhance the soil water content in the upper soil layer $(0-160 \mathrm{~cm})$. The soil water content at lower soil layer in the cropland was apparently smaller than that in the treebelt and desert (Fig. 3 and Table 2). 
The above soil water content differences were mainly attributed to vegetation water consumption and the root effect as well as groundwater recharge. Different vegetation types had different evapotranspiration, which influenced the water loss from the soil. In the study area, the mean evapotranspiration rate was $4.18 \mathrm{~mm} \mathrm{~d}^{-1}$ for maize (Zhao et al., 2010), and the value was $3.90 \mathrm{~mm} \mathrm{~d}^{-1}$ for Gansu Poplar (Chang et al., 2006) and $3.68 \mathrm{~mm} \mathrm{~d}^{-1}$ for korshinsk peashrub (Xia et al., 2008). The soil water loss rate after irrigation was higher in the cropland than that in the same soil layers of treebelt above $160 \mathrm{~cm}$ depth (Fig. 7).

The differences in the rooting systems (i.e., the roots distribution and hydraulic lift) led to different soil water content dynamics (Jost et al., 2012). Maize had shallow roots with approximately $90 \%$ of roots concentrated in $0-40 \mathrm{~cm}$ depth and the measured maximum rooting depth was $120 \mathrm{~cm}$, whereas the roots of Gansu Poplar and korshinsk peashrub were found at $320 \mathrm{~cm}$ depth (Fig. 9). Soil water in the cropland at the deeper layers $(160-280 \mathrm{~cm})$ replenished from the upper soil layer was lost by percolation into groundwater due to scarce distribution of roots (Fig. 9) and high sand content (Table 1). Similar result was found by Ellis et al. (2005) who reported that the conversion of natural vegetation to agriculture in southern Australia increased deep percolation. Deep percolation could account for approximate $43 \%$ of irrigation water for the maize in the study area obtained from soil water balance simulation (Ji et al., 2007). In contrary to cropland, the treebelt and desert shrub with deeper root could capture water percolation (Kizito et al., 2007) and suck up water from the groundwater to replenish the dry layers by the hydraulic lift of roots (Caldwell et al., 1998; Kizito et al., 2012). The groundwater uptake by vegetation was a critical water source for the growth of treebelt and desert in the arid inland river basin. The groundwater recharge accounted for $80 \%$ of the evapotranspiration by Quercus douglasii during the dry summer in the semiarid oak savannah with water table depth between 7 and $12 \mathrm{~m}$ (Miller et al., 2010).

\subsection{Hydrological relations between adjacent land use types}

The hydrological relation between the cropland and treebelt is very important for the survival of trees facing severe drought conditions in arid and semiarid areas. In addition to the groundwater recharge, the

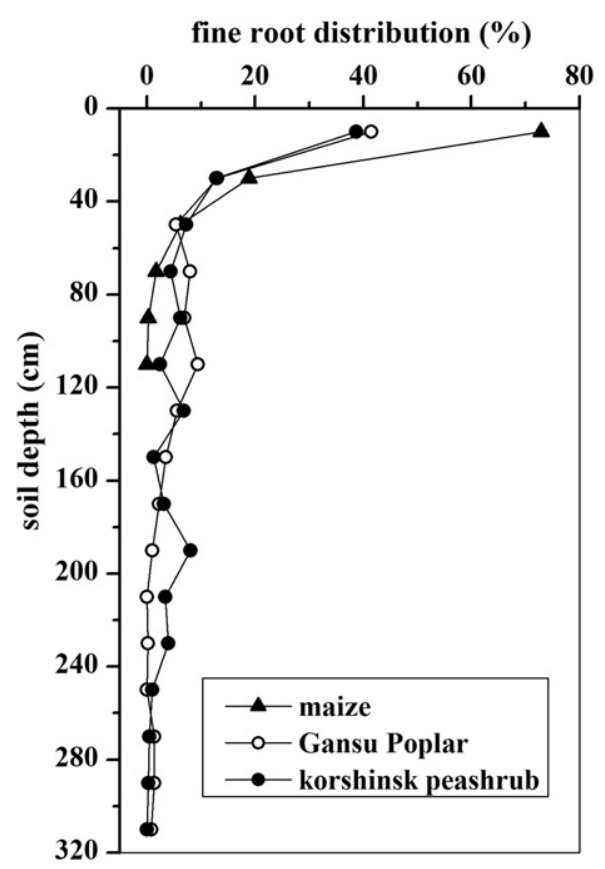

Fig. 9. The fine root distribution of maize, Gansu Poplar and korshinsk peashrub in the cropland, treebelt and desert, respectively.

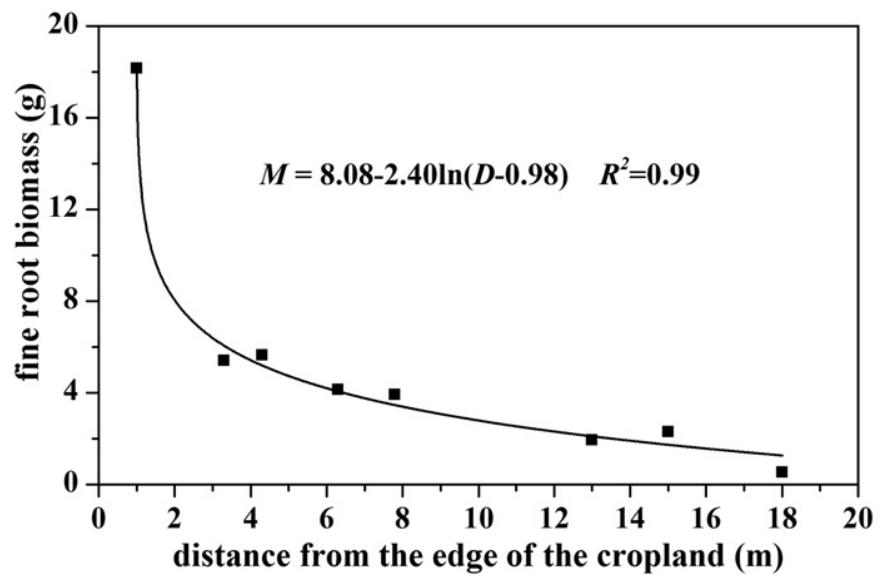

Fig. 10. The relation between the biomass of fine treebelt root extended into the cropland with the distance from the cropland-treebelt interface.

root uptake from soil water in the cropland was important source required by the treebelt (Cubera and Moreno, 2007). As evident from Fig. 10, the tree roots could extend to the cropland with a distance of at least $18 \mathrm{~m}$. Quantitative calculation revealed that more than $50 \%$ of the water transpired by the olive trees came from the neighboring annual crop plot in an olive tree-annual crop intercropping system in Central Tunisia (Abid Karray et al., 2008). With the root water uptake from the cropland, the treebelt near the cropland (the diameter at breast height was $37 \mathrm{~cm}$ ) grew better than those away from the cropland (the diameter at breast height was $21 \mathrm{~cm}$ ). Moreover, the maize near the treebelt had a lower leaf area index and plant height than that away from the treebelt. This phenomenon was consistent with the study of Miller and Pallardy (2001) that trenching with a root barrier treatment at the crop-tree interface could increase the maize grain yield by thirty-two percentage with respect to the treatment without root barrier.

The soil water content in the cropland at the depth of 0-160 cm decreased with greater proximity to the treebelt, and similar trend was reported in a hedge-maize system (Rosecrance et al., 1992) and grevillea-maize system (Livesley et al., 2004). Moreover, soil water storage loss amount was obviously higher at the point near the treebelt (C4) than the other points in the cropland (C1, C2 and C3) (Fig. 8). The soil water content gradient in the upper layer of cropland was mainly attributed to the treebelt root distribution in the cropland. First, the roots of the tree extended to the cropland located only in the upper soil layer $(0-160 \mathrm{~cm})$. Second, the biomass of fine treebelt root in the cropland decreased logarithmically with the distance from the croplandtreebelt interface (Fig. 10), which resulted in the stronger root water uptake from cropland with more proximity to the treebelt.

The hydrological relation between treebelt and desert was not obviously observed from this study. The hydrological relation in the lower soil layer among cropland-treebelt-desert was mainly caused by groundwater recharge. The deep percolation from cropland irrigation recharged into groundwater, and raised the groundwater level, which replenished the soil water in the deep soil layer of the three land use types (Fig. 11). The response in the desert showed somewhat lag behind the cropland and treebelt. Therefore, the cropland irrigation replenished the root distribution area, and the deep percolation from cropland was an important water source for the growth of treebelt and desert plants.

\section{Summary and conclusion}

In this study, the volumetric soil water content and plant root distribution was measured to the depth of $300 \mathrm{~cm}$ along a cropland-treebeltdesert site in the oasis-desert ecotone of the Heihe River Basin. The soil 


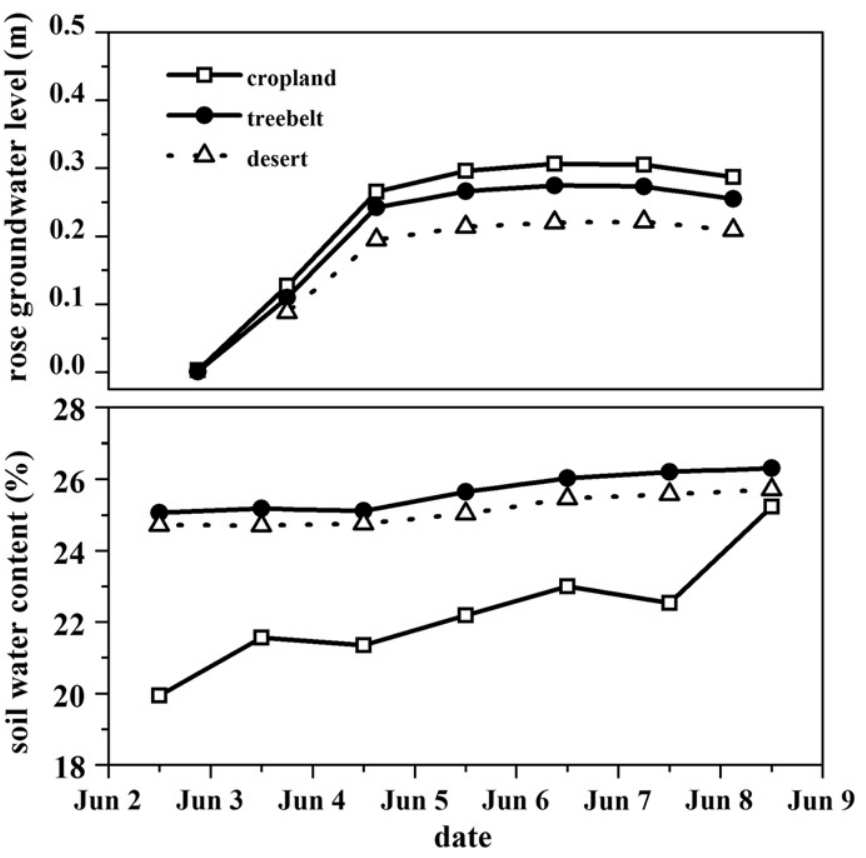

Fig. 11. The rose groundwater level and soil water content response in the deep layer $(240-280 \mathrm{~cm})$ of the three land use types after the cropland irrigation on June 3.

water content variations and hydrological relations of this land use pattern were explored. The following conclusions can be drawn:

(1) At the upper soil layer of $0-200 \mathrm{~cm}$ depth, the mean soil water content was in the descending order of cropland (8.88\%), treebelt (5.78\%) and desert (4.37\%). However, below $200 \mathrm{~cm}$ depth the cropland had noticeably lower soil water content (14.27\%) compared with the treebelt (18.07\%) and desert (17.30\%). This difference was caused by the deep percolation in the cropland as a result of its shallow distribution of roots, whereas the treebelt and desert shrub with deeper roots could suck up groundwater to replenish the deep soil layers.

(2) There were distinct soil water content pulses in the upper soil layers of cropland and treebelt after irrigation events, and the decline process of soil water content could be well described by an exponential decay function. Furthermore, the soil water loss rate decreased with the depth, and it was higher in the cropland than that in the treebelt at the same soil layer. In the desert, the soil water content was relatively stable except for some variations at the surface and bottom soil layers.

(3) The roots of the tree extended to the cropland located only in the upper soil layer $(0-160 \mathrm{~cm})$, and the biomass decreased logarithmically with the distance from the cropland-treebelt interface. The treebelt root water uptake from cropland resulted in the smaller soil water content in the cropland with more proximity to the treebelt. The cropland irrigation raised up the groundwater level to replenish the deep soil layer of cropland-treebeltdesert, resulted in the hydrological relation among the land use pattern.

This study indicated that the combined effects of irrigation, vegetation evapotranspiration, deep percolation and groundwater recharge resulted in the complex soil water content variations and hydrological relations in different soil layers of the cropland-treebelt-desert land use pattern. The results are very meaningful to the soil water management for the balance between vegetation construction and agricultural production in the water limited area. This study is useful for optimal design of land use pattern and efficient protection of oasis ecosystem, and it can provide scientific support for water resources and land use management in the arid inland river basin. Further studies are needed to substantially investigate the relative roles of above factors and detect quantitative hydrological relations with the help of isotope tracing and model simulation.

\section{Acknowledgements}

This research was financially supported by the National Natural Science Foundation of China (91025018 and 91025002), and the 12th five year science and technology development program (2012BAC08B01). We would like to thank the Linze Inland River Basin Research Station Experimental for field experiment support. We thank the anonymous reviewers for their constructive comments which improved the overall quality of the manuscript.

\section{References}

Abid Karray, J., Lhomme, J.P.,Masmoudi, M.M.,Ben Mechlia, N., 2008. Water balance of the olive tree-annual crop association: A modeling approach. Agric. Water Manag. 95, 575-586.

Caldwell, M.M.,Dawson, T.E., Richards, J.H., 1998. Hydraulic lift: consequences of water efflux from the roots of plants. Oecologia 113, 151-161.

Campi, P.,Palumbo, A.D., Mastrorilli, M., 2009. Effects of tree windbreak on microclimate and wheat productivity in a Mediterranean environment. Eur. J. Agron. 30, 220-227.

Chang, X.X., Zhao, W.Z., Zhang, Z.H., Su, Y.Z., 2006. Sap flow and tree conductance of shelter-belt in arid region of China. Agric. For. Meteorol. 138, 132-141.

Coronato, F.R., Bertiller, M.B., 1996. Precipitation and landscape related effects on soil moisture in semi-arid rangelands of Patagonia. J. Arid Environ. 34, 1-9.

Cubera, E., Moreno, G., 2007. Effect of land-use on soil water dynamic in dehesas of Central-Western Spain. Catena 71, 298-308.

Dodd, M.B., Lauenroth, W.K., 1997. The influence of soil texture on the soil water dynamics and vegetation structure of a shortgrass steppe ecosystem. Plant Ecol. 133, 13-28.

Ellis, T.,Hatton, T., Nuberg, I., 2005. An ecological optimality approach for predicting deep drainage from tree belts of alley farms in water-limited environments. Agric. Water Manag. 75, 92-116.

Entin, J.K., Robock, A.,Vinnikov, K.Y.,Hollinger, S.E.,Liu, S.,Namkhai, A., 2000. Temporal and spatial scales of observed soil moisture variations in the extratropics. J. Geophys. Res. $105,11865-11877$.

Fu, B.J.,Wang, J.,Chen, L.D., Qiu, Y., 2003. The effects of land use on soil moisture variation in the Danangou catchment of the Loess Plateau, China. Catena 54, 197-213.

Hu, W.,Shao, M.A.,Wang, Q.J., Reichardt, K., 2008. Soil water content temporal-spatial variability of the surface layer of a Loess Plateau hillside in China. Sci. Agric. 65, 277-289.

Hu, W.,Shao, M.A., Han, F.P., Reichardt, K., 2011. Spatio-temporal variability behavior of land surface soil water content in shrub-and grass-land. Geoderma 162, 260-272.

Huang, Y.L., Chen, L.D., Fu, B.J., Huang, Z.L., Gong, J., Lu, X.X., 2012. Effect of land use and topography on spatial variability of soil moisture in a gully catchment of the Loess Plateau, China. Ecohydrology 5, 826-833.

Ji, X.B., Kang, E.S., Chen, R.S.,Zhao, W.Z.,Zhang, Z.H.,Jin, B.W., 2007. A mathematical model for simulating water balances in cropped sandy soil with conventional flood irrigation applied. Agric. Water Manag. 87, 337-346.

Jost, G., Schume, H., Hager, H., Markart, G., Kohl, B., 2012. A hillslope scale comparison of tree species influence on soil moisture dynamics and runoff processes during intense rainfall. J. Hydrol. 420, 112-124.

Kizito, F.,Sène, M.,Dragila, M.I.,Lufafa, A.,Diedhiou, I.,Dossa, E.,Cuenca, R.,Selker, J.,Dick, R P., 2007. Soil water balance of annual crop-native shrub systems in Senegal's Peanut Basin: The missing link. Agric. Water Manag. 90, 137-148.

Kizito, F., Dragila, M.I., Senè, M., Brooks, J.R., Meinzer, F.C., Diedhiou, I., Diouf, M., Lufafa, A. Dick, R.P., Selker, J., Cuenca, R., 2012. Hydraulic redistribution by two semi-arid shrub species: Implications for Sahelian agro-ecosystems. J. Arid Environ. 83, 69-77.

Knight, A., Blott, K., Portelli, M., Hignett, C., 2002. Use of tree and shrub belts to contro leakage in three dryland cropping environments. Aust. J. Agric. Res. 53, 571-586.

Li, X.R., He, M.Z., Jia, R.L., 2008. The response of desert plant species diversity to the changes in soil water content in the Middle-1ower reaches of the Heihe River. Adv. Earth Sci. 23, 685-691 (in Chinese).

Liu, B.,Zhao, W.Z.,Chang, X.X.,Li, S.B.,Zhang, Z.H.,Du, M.W., 2010. Water requirements and stability of oasis ecosystem in arid region, China. Environ. Earth Sci. 59, 1235-1244.

Livesley, S.J.,Gregory, P.J.,Buresh, R.J., 2004. Competition in tree row agroforestry systems. 3. Soil water distribution and dynamics. Plant Soil 264, 129-139.

Mahmood, R.,Hubbard, K.G., 2007. Relationship between soil moisture of near surface and multiple depths of the root zone under heterogeneous land uses and varying hydroclimatic conditions. Hydrol. Process. 21, 3449-3462.

Miller, A.W., Pallardy, S.G., 2001. Resource competition across the crop-tree interface in a maize-silver maple temperate alley cropping stand in Missouri. Agrofor. Syst. 53, 247-259.

Miller, G.R., Chen, X.Y., Rubin, Y., Ma, S.Y., Baldocchi, D.D., 2010. Groundwater uptake by woody vegetation in a semiarid oak savanna. Water Resour. Res. 46, W10503. http://dx.doi.org/10.1029/2009WR008902.

Porporato, A., D'odorico, P., Laio, F., Ridolfi, L., Rodriguez-Iturbe, I., 2002. Ecohydrology of water-controlled ecosystems. Adv. Water Resour. 25, 1335-1348. 
Qiu, Y.,Fu, B.J., Wang, J., Chen, L.D., 2003. Spatialtemporal prediction of soil moisture content using multiple-linear regression in a small catchment of the Loess Plateau, China. Catena 54, 173-195.

Rosecrance, R.C., Brewbaker, J.L., Fownes, J.H., 1992. Alley cropping of maize with nine leguminous trees. Agrofor. Syst. 17, 159-168.

Ruiz-Sinoga, J.D., Gabarrón Galeote, M.A., Martinez Murillo, J.F., Garcia Marín, R., 2011. Vegetation strategies for soil water consumption along a pluviometric gradient in southern Spain. Catena 84, 12-20.

Singh, J.S.,Milchunas, D.G.,Lauenroth, W.K., 1998. Soil water dynamics and vegetation patterns in a semiarid grassland. Plant Ecol. 134, 77-89.

Su, Y.Z.,Zhao, W.Z.,Su, P.X.Zhang, Z.H.,Wang, T.,Ram, R., 2007. Ecological effects of desertification control and desertified land reclamation in an oasis-desert ecotone in an arid region: a case study in Hexi Corridor, northwest China. Ecol. Eng. 29, 117-124.

Valentin, C., d'Herbes, J.M., Poesen, J., 1999. Soil and water components of banded vegeation patterns. Catena 37, 1-24.

Wang, G.X., Cheng, G.D., 1999. Water resource development and its influence on the environment in arid areas of China-the case of the Hei River basin. J. Arid Environ. $43,121-131$.
Wang, G.X.,Liu, J.Q..Kubota, J.,Chen, L., 2007a. Effects of land-use changes on hydrological processes in the middle basin of the Heihe River, northwest China. Hydrol. Process. $21,1370-1382$

Wang, H.,Zhao, W.Z.,Chang, X.X., 2007b. Spatial variability of soil moisture and vegetation in desert-oasis ecotone in the middle reaches of Heihe River Basin. Acta Ecol. Sin. 27, 1731-1739 (in Chinese).

Woodall, G.S.,Ward, B.H., 2002. Soil water relations, crop production and root pruning of a belt of trees. Agric. Water Manag. 53, 153-169.

Xia, G.M., Kang, S.Z.,Li, F.S.,Zhang, J.H.,Zhou, Q.Y., 2008. Diurnal and seasonal variations of sap flow of Caragana korshinskii in the arid desert region of north-west China. Hydrol. Process. 22, 1197-1205.

Zhao, W.Z.,Liu, B., 2010. The response of sap flow in shrubs to rainfall pulses in the desert region of China. Agric. For. Meteorol. 150, 1297-1306.

Zhao, W.Z., Liu, B.,Zhang, Z.H., 2010. Water requirements of maize in the middle Heihe River basin, China. Agric. Water Manag. 97, 215-223. 